\title{
REPRESENTASI SITUASI SOSIAL DAN KONSTRUKSI IDEOLOGI DALAM PIDATO PELANTIKAN ANIES BASWEDAN
}

\author{
Rinta Alvionita \\ Program Studi Ilmu Linguistik, Universitas Gadjah Mada \\ Jalan Sosio Humaniora, Bulaksumur, Sleman, Yogy akarta \\ Surel: rinta.alvionita@mail.ugm.ac.id
}

Informasi Artikel:
Dikirim: 20 Januari 2018; Dire visi: 5 Februari 2018; Diterima: 11 Februari 2018
DOI: 10.26858/retorika.v11i1.4994
RETORIKA: Jurnal Bahasa, Sastra dan Pengajarannya berada di bawah lisensi
Creative Commons Attribution-NonCommercial 4.0 International License.
ISSN: 2614-2716 (cetak), ISSN: 2301-4768 (daring)
http://ojs.unm.ac.id/retorika

\begin{abstract}
Representation of Social Situation and Ideology Construction in Anies Baswedan's Inauguration Speech. This research investigates the representataion of the social situations of Jakarta current issues found in Anies Baswedan's speech at Governor and Vice Governor inauguration and the reveal of ideology as reflected in the speech. The method used in this research is a qualitative-critical linguistic focusing on the analysis of language metafunctions. The results indicate that the representation of the social situation in DKI Jakarta in view of Anies Baswedan's speech reflects certain ideology depicting the criticism and the spotlight on the issue of justice, prosperity, colonialis $m$, indigenous and independence. This ideology is somewhat based on the use of language in his speech as an attempt to shape the self-image of having efforts to be 'a pro-people and better governor'.
\end{abstract}

\begin{abstract}
Abstrak. Representasi Situasi Sosial dan Konstruksi Ideologi dalam Pidato Pelantikan Anies Baswedan. Penelitian ini bertujuan mendeskripsikan representasi situasi sosial dan mengungkapkan dan menjelaskan ideologi yang tercermin dalam pidato Anies Baswedan pada pelantikan Gubernur dan Wakil Gubernur DKI Jakarta periode 2017-2022. Metode yang digunakan adalah metode kualitatif-linguistik kritis yang berfokus pada analisis metafungsi bahasa. Hasil penelitian menunjukkan bahwa representasi situasi sosial DKI Jakarta dalam pidato Anies Baswedan mencerminkan adanya ideologi tertentu, yaitu kritik dan sorotan terhadap masalah keadilan, kesejahteraan, penjajahan, pribumi, dan kemerdekaan. Ideologi ini sekaligus melatarbelakangi penggunaan bahasa dalam pidatonya sebagai upaya untuk membentuk citra 'gubernur yang akan bertindak pro-rakyat dan menjadi lebih baik'.
\end{abstract}

Kata Kunci: analisis wacana kritis, ideologi, representasi, systemic functional linguistics 
Setelah kolonialisme berakhir, istilah pribumi berubah dari yang semula digunakan sebagai istilah propaganda nasionalis menjadi istilah yang merujuk pada rasisme. Sejak tahun 1998, Pemerintah Republik Indonesia secara resmi melarang penggunaan istilah pribumi dan menggantinya menjadi Warga Negara Indonesia (WNI) sesuai dengan Instruksi Presiden Nomor 26 Tahun 1998 dan Undang-Undang Republik Indonesia Nomor 40 Tahun 2008. Isu pribumi, kembali muncul dalam satu tahun terakhir, salah satunya adalah penyebutan istilah pribumi dalam pidato pelantikan Anies Baswedan (AB) sebagai gubernur DKI Jakarta periode 2017-2022.

Fenomena penggunaan bahasa dalam pidato $\mathrm{AB}$ sebagai salah satu tokoh masyarakat dapat dikaji secara kritis dengan pendekatan Analisis Wacana Kritis (AWK). Hal ini menjadi perhatian serta sorotan khusus di kalangan masyarakat karena sebagai seorang pejabat pemerintah, penggunaan bahasa $\mathrm{AB}$ mencerminkan kepentingan tertentu yang disampaikan kepada masyarakat melalui representasi dan ideologi yang dibangun $\mathrm{AB}$ dalam pidatonya. Representasi yang dimaksud merupakan cara $\mathrm{AB}$ medeskripsikan situasi sosial di DKI Jakarta yang meliputi: identitas DKI Jakarta di masa lalu, situasi beberapa waktu terakhir, dan harapan yang akan dicapai di masa yang akan datang berdasarkan fitur-fitur bahasa. Selain itu, pidato tersebut merupakan wacana yang mencerminkan ideologi tertentu dan membentuk kognisi sosial, yaitu hubungan antara wacana dan ideologi (Fairclough, 2001).

Analisis yang dimaksud tidak hanya berfokus pada satu istilah 'pribumi' yang diucapkan $\mathrm{AB}$, melainkan seluruh ungkapan untuk mengetahui ideologi yang terkonstruksi melalui pidato tersebut yang melatarbelakangi tersorotnya pidato Anies hingga menjadi kontroversi di kalangan masyarakat. Fairclough (2001:3) menyatakan bahwa memfokuskan perhatian pada ideologi wacana berarti membantu orang untuk melihat sejauh mana bahasa mereka mengandung asumsi akal sehat dan bagaimana asumsi ini dapat dibentuk secara ideologis dengan hubungan kekuasaan. Hal ini sejalan dengan posisi $A B$ sebagai salah satu tokoh masyarakat yang tidak terlepas dari kekuasaannya sebagai seorang pemimpin. Dengan demikian, penelitian ini menjadi salah satu fenomena wacana politik dalam khazanah ilmu analisis wacana kritis yang dapat menunjukkan situasi sosial yang terepresentasi dan terkonstruksi melalui ideologi dalam pidato tokoh.
Penggunaan SFL (Systemic Functional Linguistics) dalam kerangka teori AWK telah dilakukan sebelumnya oleh beberapa peneliti. Hernandez (2008) menunjukkan kontribusi SFL dan AWK untuk menemukan identitas nasional seseorang pada artikel koran di Inggris dan Spanyol melalui sistem transitivitas pada level konstruksi wacana. Penelitian ini membuktikan bahwa identitas komunitas Gibraltar dalam konflik politik antarkedua negara tersebut direpresetasikan sebagai entitas pasif. Identitas tersebut dipengaruhi oleh proses mental dalam konstruksi wacana yang dibangun melalui harapan dan opininya.

Penelitian yang mengungkapkan ideologi dengan pendekatan AWK yang juga berfokus pada isu politik dilakukan oleh Faridi (2014) pada berita politik dalam Koran Radar Madura menjelang pemilu legislatif 2014. Analisis dalam penelitian Faridi berfokus pada deskripsi tentang representasi ideologi dalam teks berita politik yang tercermin melalui kosa kata dan tata bahasa. Penelitian tersebut menunjukkan kosakata asosiasi dalam menggambarkan realitas sebagai klasifikasi, marjinalisasi, pembatasan pandangan dan pertarungan wacana, kosa kata metafora untuk menunjukkan labelling negatif dan positif, dan representasi tata bahasa proses dan partisipan digunakan wartawan Radar Madura dalam menggambarkan realitas sebagai tindakan, peristiwa, keadaan, dan proses mental. Kemudian ideologi secara tersirat terungkap berdasarkan representasi kosa kata dan tata bahasa, yaitu ideologi ekonomi, ideologi politis, dan ideologi kekuasaan.

Penelitian ini memperdalam penggunaan teori SFL dalam kerangka teori AWK baik untuk menunjukkan representasi situasi sosial di DKI Jakarta serta ideologi yang tercermin melalui pidato pelantikan AB. Analisis yang digunakan mencakup tiga level kerangka teori AWK yang dikemukakan oleh Fairclough (1995), yakni analisis tekstual, analisis praktik wacana, dan analisis praktik sosiokultural. Dengan demikian, penelitian ini memiliki tiga tujuan utama, yaitu: (1) mendeskripsikan representasi situasi sosial di DKI Jakarta dalam pidato AB pada pelantikan Gubernur dan Wakil Gubernur DKI Jakarta periode 2017-2022 melalui tahap analisis tekstual, yaitu pilihan kata, transitivitas, dan sistem appraisal (2) mendeskripsikan representasi situasi sosial tersebut dengan menggunakan interpretasi teks dan kontaks, dan (3) mengungkapkan serta menjelaskan ideologi tercermin berdasarkan ke- 
dua aspek tersebut. Dengan demikian, aspek-aspek tekstual dan interpretasi teks dan konteks melalui praktik wacana digunakan untuk merepresentasikan situasi sosial di DKI Jakarta dan akhirnya ideologi yang terekonstruksi melalui pidato tersebut diungkapkan berdasarkan penggunaan bahasa dalam pidato $\mathrm{AB}$.

Semua kata-kata merupakan sebuah interpretasi atau representasi dari sebuah refleksi (Fowler, 1996:18). Representasi menunjukkan penggunaan bahasa dalam suatu wacana agar dipahami secara jelas karena pembuat wacana dapat mendeskripsikan atau menggambarkan gagasan atau pemikirannya terhadap realitas sosial (Eriyanto, 2009). Representasi dapat ditelusuri dalam teks dengan memanfaatkan kerangka analisis Fairclough (1995:2001) dan Halliday (1994), terutama struktur kalimat. Analisis struktur kalimat mencakup analisis tekstual dalam tahap deskripsi yang pembahasannya terpusat pada kajian SFL yang terdiri atas tiga metafungsi bahasa, yaitu fungsi tekstual, fungsi ideasional, dan fungsi interpersonal.

Salah satu aspek fungsi tekstual untuk mengidentifikasi representasi adalah pilihan kata. AWK melihat cara pilihan kata membawa posisi dan ideologi tertentu (Fairclough, 1995). Dalam fungsi ideasional melalui transitivitas sebagai salah satu bagian dari tata bahasa juga dapat digunakan untuk menemukan representasi. Dalam fungsi interpersonal, sistem appraisal atau evaluasi yang menyatakan makna dalam suatu wacana dengan melibatkan kekuatan emosional juga digunakan untuk mengetahui representasi yang digunakan oleh pembuat wacana. Dengan demikian, representasi melalui ketiga fungsi bahasa dan interpretasi teks dan konteks digunakan sebagai landasan untuk mengungkapkan ideologi yang tersirat dari satu wacana.

Penelitian ini bertujuan mendeskripsikan representasi situasi sosial dan mengungkap serta menjelaskan ideologi yang tercermin dalam pidato $\mathrm{AB}$ pada pelantikan Gubernur dan Wakil Gubernur DKI Jakarta periode 2017-2022. Hasil penelitian memberi kontribusi terhadap pengembangan kerangka analisis wacana kritis, utamanya dalam wacana politik.

\section{METODE}

Penelitian ini merupakan penelitian deskriptif-kualitatif dengan menggunakan pendekat- an analisis wacana kritis (Basrowi, 2008). Data dalam penelitian ini adalah teks pidato $\mathrm{AB}$ saat pelantikan Gubernur dan Wakil Gubernur DKI Jakarta pada tanggal 16 Oktober 2017 yang diperoleh dari laman pemerintah Provinsi DKI Jakarta, yaitu http://www.jakarta.go.id. Data yang digunakan dalam penelitian ini dibatasi pada data yang mengandung representasi situasi sosial di DKI Jakarta melalui tahap analisis tekstual, yaitu (1) pilihan kata, (2) transitivitas, dan (3) sistem appraisal. Ideologi yang tercermin dalam pidato tersebut diungkapkan dan dijelaskan berdasarkan kerangka teori.

Teknik analisis dalam penelitian ini menggunakan analisis linguistik kritis yang terdiri dari tahapan deskripsi, interpretasi dan eksplanasi (Fairclough, 1995:198). Metode analisis data berupa metode padan referensial berupa analisis dokumen (Sudaryanto, 1993:13). Klasifikasi analisis data berupa teks pidato Anis Baswedan dalam bentuk klausa atau kalimat. Analisis data berfokus pada (1) tahap analisis teks yang menitikberatkan pada analisis metafungsi bahasa dalam SFL, yaitu fungsi tekstual, fungsi ideasional, dan fungsi interpersonal untuk menjelaskan representasi situasi sosial di DKI Jakarta melalui pidato $A B$; (2) tahap analisis praktik wacana berupa interpretasi teks dari aspek analisis tekstual yang didasarkan pada konteks situasional, dan (3) pengungkapan dan penjelasan ideologi yang tercermin berdasarkan kedua aspek analisis tersebut.

\section{HASIL DAN PEMBAHASAN}

\section{Analisis Tekstual Situasi Sosial di DKI Jakarta}

Penggunaan bahasa dalam pidato $\mathrm{AB}$ merepresentasikan situasi sosial DKI Jakarta pada satu tahun terakhir ini. Analisis mengenai representasi tersebut dijelaskan sebagai berikut.

\section{Pilihan Kata dalam Fungsi Tekstual}

Pilihan kata sangat menentukan cara realitas sosial diwujudkan dalam bahasa dan cara bahasa pada akhirnya mengkonstruksi realitas tertentu (Fairclough, 1995). Pilihan kata merupakan salah satu aspek tekstual yang digunakan untuk mengetahui representasi atas realitas sosial melalui suatu wacana. Adapun fokus pilihan kata terangkum dalam empat tujuan utama (Fowler, 
1991) yaitu (1) membentuk klasifikasi, (2) membatasi pendangan, (3) pertarungan wacana, dan (4) marginalisasi. Representasi situasi sosial yang diungkapkan $\mathrm{AB}$ dalam pidatonya dapat diidentifikasi melalui pilihan kata tersebut.

\section{Membentuk Klasifikasi}

Data (1) dan (2) berikut ini menunjukkan klasifikasi pidato $\mathrm{AB}$ berdasarkan realitas yang terjadi di masa lalu dan masa sekarang.

(1) Dulu kita semua pribumi, ditindas dan dikalahkan.

(2) Kini telah merdeka, kini saatnya menjadi tuan rumah di negeri sendiri.

Klasifikasi terhadap realitas masa lampau ditunjukkan pada data (1) dengan pilihan kata dulu. Pilihan kata tersebut menjelaskan realitas bahwa perjuangan masyarakat Jakarta sudah dilalui sejak era mereka masih merasakan diskriminasi dari peristiwa kolonialisme. Jakarta pernah menjadi kota yang masyarakatnya (kelompok 'pribumi') pernah merasakan ketidakadilan. Klasifikasi terhadap realitas masa sekarang ditunjukkan pada data (2) dengan pilihan kata kini. Kosakata tersebut menjelaskan realitas yang terjadi setelah kolonialisme berakhir sekaligus menunjukkan masa pemerintahan $\mathrm{AB}$ yang dianggap akan membawa kebaikan, keadilan, dan perubahan baru yang bebas dari diskriminasi terhadap penduduk asli Jakarta. Klasifikasi terhadap masa sekarang pada data tersebut sekaligus menegaskan awal perjuangan baru bagi Jakarta yang diharapkan bisa lebih maju dari sebelumnya dibawah pemerintahan AB dan Sandiaga Uno. Klasifikasi-klasifikasi tersebut bertujuan untuk menunjukkan adanya perbandingan situasi Indonesia yang dahulu dianggap pernah mengalami penjajahan pada masa kolonialisme dan masa sekarang yang dianggap tidak lagi merasakan adanya ketidakadilan.

\section{Membatasi Pandangan}

Pilihan kata tertentu dalam penggunaan bahasa juga bersifat membatasi pandangan agar pemahaman pembaca atau pendengar berfokus pada peristiwa tertentu. AB melalui pidatonya mencoba menggiring pemahaman khalayak melalui pilihan kata tertentu untuk mencapai tujuan bahwa pemerintah DKI Jakarta yang baru di bawah kepemimpinannya bisa menjadi pemerin- tahan yang lebih baik dari sebelumnya. Beberapa kosakata yang digunakan $\mathrm{AB}$ untuk membatasi pandangan khalayak adalah sebagai berikut.

(3) Hari ini, saya dan Bang Sandi dilantik jadi gubernur dan wakil gubernur, bukan bagi para pemilih kami saja, tetapi bagi seluruh warga Jakarta.

(4) Di kota ini interaksi adalah bagian dari sejarahnya, dan di kota ini pula masyarakat Betawi telah menjadi sebaik-baiknya tuan rumah bagi Jakarta.

Berdasarkan data (3), frase bukan bagi para pemilih kami saja memperjelas generalisasi aktor yang merepresentasikan seluruh warga Jakarta, bukan orang-orang tertentu. Kosakata tersebut mengeneralisasi aktor yang merupakan pendengar dari pidatonya sekaligus masyarakat yang dipimpin pemerintahan $\mathrm{AB}$ mulai tahun 2017 hingga 2022. Hal ini lazim digunakan untuk menggeneralisasikan masyarakat Jakarta dengan pilihan kata tersebut, karena yang akan merasakan dampak kepemimpinan baru di bawah pemerintahan $\mathrm{AB}$ secara langsung adalah seluruh warga Jakarta. Data (4) frase masyarakat Betawi menjadi aktor yang digeneralisasikan oleh $\mathrm{AB}$ sebagai tuan rumah kota Jakarta atas peristiwa adanya hubungan antara penduduk asli Jakarta dengan luar Jakarta hingga Indonesia. Padahal tuan rumah yang dimaksud belum tentu semuanya adalah orang Betawi atau dapat dikatakan bahwa yang dimaksud $\mathrm{AB}$ adalah sebagian besar penduduk asli Jakarta adalah masyarakat Betawi. Dengan demikian, generalisasi yang dapat diamati dari pilihan kata $\mathrm{AB}$ ini digunakan untuk menggiring pemahaman khalayak untuk berada dalam satu paham dengan $\mathrm{AB}$, yaitu warga Jakarta sebagai tuan rumah diajak untuk menjaga keadilan dan persatuan seluruh warga Jakarta agar menjadi lebih baik.

\section{Pertarungan Wacana}

Pilihan kata dalam suatu wacana bertujuan untuk menguatkan gagasan atau pendapat melalui pertarungan wacana. AB menggunakan beberapa kosakata yang menunjukkan adanya pertarungan wacana untuk melakukan pembenaran dan pembuktian. Berikut data yang menunjukkan kosakata pertarungan wacana.

(5) Kota ini tidak boleh hanya sekedar perintah gubernur sampai ke bawah. De- 
ngarkan kata rakyat, maka kita hidupkan seluruh majelis-majelis yang ada di kota ini. Ada banyak sekali majelis saudarasaudara sekalian. Kita hidupkan semuanya. Kita tidak hendak membangun suatu negara untuk sekelompok orang.

Berdasarkan data (5), pertarungan wacana terlihat dari penggunaan kata penegasan tidak. Hal ini menyiratkan bahwa selama ini warga Jakarta harus saling bekerja sama dengan pemerintah, tidak hanya bergantung pada pemerintah. Selain itu, pilihan kata tersebut juga mengindikasikan penegasan bahwa warga Jakartalah yang paling banyak merasakan ketidakadilan saat era kolonialisme terjadi. Hal ini menunjukkan upaya AB untuk membuat pertarungan wacana yang seolah ada pembuat wacana lain yang tidak pernah menegaskan klaim tersebut.

\section{Marginalisasi}

Penggunaan kosakata tertentu juga bertujuan untuk membuat marginalisasi terhadap pihak atau kelompok tertentu. Pemakaian bahasa dipandang tidak netral karena membawa implikasi ideologis tertentu. Penggunaan kata tertentu digunakan sebagai ekspresi ideologi, yaitu upaya untuk membentuk pendapat umum, meneguhkan, dan membentuk pihak sendiri dan mengucilkan pihak lain (Fowler dan Kress, 1996). Marginalisasi ini dapat diamati dari pemilihan beberapa kosakata yang digunakan AB dalam pidatonya berikut ini.

(6) Dan Jakarta ini satu dari sedikit, satu dari sedikit kota di Indonesia yang merasakan kolonialisme dari dekat.

(7) Dulu kita semua pribumi ditindas dan dikalahkan.

(8) Kita yang bekerja keras untuk merebut kemerdekaan. Kita yang bekerja keras untuk mengusir kolonialisme. Kita semua harus merasakan manfaat kemerdekaan di ibukota ini.

Berdasarkan data (6), AB memarjinalkan pihak kolonial dengan menggunakan kosakata kolonialisme. Selain itu, pada data (7) kosakata yang digunakan untuk memarjinalkan pihak $k o$ lonial adalah pribumi dimana pribumi dianggap sebagai warga Jakarta yang paling merasakan penjajahan dan penindasan pada era kolonialisme. Kosakata kolonialisme kembali digunakan AB pada data (8) untuk memarjinalkan pihak kolonial. Upaya AB dalam menggunakan kosakata-kosakata tersebut bertujuan untuk membangun pemahaman masyarakat bahwa kolonialisme sudah berakhir dan berganti menjadi kemerdekaan yang sesungguhnya.

\section{Transitivitas dalam Fungsi Ideasional}

Transitivitas dalam suatu wacana berfokus pada proses material, proses mental, proses relasional, proses verbal, proses behavioral, dan proses eksistensial Halliday dan Matthiesen (2004). Penelitian ini hanya berfokus pada empat proses yang pertama sesuai data yang ditemukan.

\section{Proses Material}

Proses material perbuatan (actions). Proses material perbuatan mewajibkan hadirnya partisipan (actor), verba tindakan, dan sasaran (goal) agar informasi yang disampaikan kepada khalayak dapat diterima dengan lengkap.

(9) Kita yang bekerja keras untuk merebut kemerdekaan. Kita yang bekerja keras untuk mengusir kolonialisme.

Data (9) menunjukkan klausa yang mengandung proses material perbuatan yang terdiri atas partisipan yang menduduki peran aktor, verba tindakan, dan sasaran. Berdasarkan klausa pertama yang digarisbawahi tersebut, verba tindakan bekerja keras dan merebut memiliki makna 'perbuatan' serta menuntut hadirnya aktor dan sasaran agar bersifat transitif dan informasi yang disampaikan lengkap. Aktor dalam klausa tersebut adalah pronomina persona kita dimana $\mathrm{AB}$, Sandiaga Uno beserta masyarakat menjadi pelaku dan kemerdakaan sebagai sasaran atas verba tindakan tersebut. Kemudian klausa kedua juga mengandung verba tindakan bekerja keras dan mengusir yang memiliki makna 'perbuatan' serta aktor berupa pronomina persona kita dan kolonialisme sebagai sasarannya. Dengan demikian, sebagai pemimpin baru Jakarta, AB beserta Sandiaga Uno dan masyarakat Jakarta untuk memperoleh kemerdekaan yang sesungguhnya dari kolonialisme. Berdasarkan proses material tindakan yang diungkapkan AB tersebut, terlihat bahwa klausa tersebut digunakan untuk merepresentasikan pemerintahan yang tidak ingin melupakan terjadinya kolonialisme hingga terbayarkan dengan kemerdekaan bagi seluruh warga Indonesia. 
Proses material kejadian (events). Proses material ini memiliki makna 'kejadian' yang dapat diidentifikasi melalui peristiwa yang terjadi dalam wacana. Proses material 'kejadian' dapat berupa kalimat aktif maupun pasif, yaitu baik aktor maupun sasaran sama-sama dapat ditonjolkan dalam kalimat tersebut. Berikut ini merupakan data yang menunjukkan proses material 'kejadian' dalam pidato $\mathrm{AB}$.

(10) Dulu kita semua pribumi ditindas dan dikalahkan. Kini telah merdeka, kini saatnya menjadi tuan rumah di negeri sendiri

Data (10) menunjukkan adanya proses material kejadian pada era kolonialisme yang menjelaskan kejadian penindasan orang pribumi sebagai tuan rumah Indonesia belum mempero-leh kemerdekaan. Melalui klausa tersebut, AB berupaya menunjukkan representasi pemerintah yang juga mengutamakan keadilan dan kebebasan bagi warga Jakarta. Hal tersebut sekaligus menjadi informasi bahwa kejadian 'penindasan' tersebut telah dialami langsung oleh rakyat. Dengan proses material 'tindakan' yang terwujud dalam pidato $\mathrm{AB}$ tersebut, representasi pemerintah yang menunjunjung tinggi keadilan bagi seluruh warga Jakarta dapat diidentifikasi secara tersirat.

\section{Proses Mental}

Proses mental dalam suatu wacana tidak terlepas dari proses merasakan (sensing). Adapun partisipan dalam proses mental meliputi perasa (senser) dan fenomena. Proses mental 'perseptif' melibatkan indera manusia, yaitu indera pendengar, penglihat, penciuman, pengecap, dan peraba. Berikut data yang menunjukkan proses mental 'perseptif' yang mengandung kegiatan melihat.

(11) Dan Jakarta ini satu dari sedikit, satu dari sedikit kota di Indonesia yang merasakan kolonialisme dari dekat. Penjajahan di depan mata itu di Jakarta, selama ratusan tahun. Di tempat lain mungkin penjajahan terasa jauh, tapi di Jakarta bagi orang Jakarta yang namanya kolonialisme itu di depan mata. Dirasakan sehari-hari.

Data (11) menunjukkan bahwa rakyat Jakarta melihat kolonialisme secara langusung dan dekat, meskipun maksud tersebut tidak diungkapkan secara eksplisit dengan verba melihat atau menyaksikan tetapi menggunakan verba me- rasakan. Kemudian senser dari verba tersebut adalah Jakarta dan fenomenanya adalah kolonialisme dari dekat, penajajahan di depan mata, dan kolonialisme di depan mata. Hal ini menunjukkan bahwa kondisi Jakarta pada saat itu masih penuh dengan ketidakadilan yang dirasakan dan dilihat secara langsung oleh warga Jakarta. Berdasarkan uraian proses mental 'perseptif' tersebut, khususnya dari kegiatan 'melihat', dapat diketahui bahwa $\mathrm{AB}$ ingin menunjukkan kepada warga Jakarta tentang kepeduliannya terhadap keadilan, kesejahteraan, dan keamanan bagi seluruh rakyat Jakarta.

\section{Proses Relasional}

Proses relasional dimaknai sebagai sebuah proses yang menghubungkan suatu fragmen kejadian dengan fragmen kejadian lainnya. Halliday dan Matthiessen (2004:210) memaknai proses rasional sebagai the process of having and being. Proses relasional dibagi menjadi dua jenis, yakni proses relasional atributif dan proses relasional identifikatif.

Proses relasional atributif. Partisipan dalam proses ini disebut sebagai pemilik (carrier) dan penjelas yang disebut sebagai atribut (attribute). Dalam pidato $\mathrm{AB}$, ditemukan data yang berbentuk relasional atributif dengan karakteristik berupa verba posesif yang menyatakan kepemilikan. Proses ini digunakan untuk melihat proses kepemilikan yang terjadi antara pembuat wacana dan pihak yang disinggung atau yang bersangkutan.

(12) Persatuan dan keguyuban ini yang harus kita perjuangkan. Dimulai dari meruntuhkan sekat-sekat yang menjadi penghalang interaksi antarkomponen masyarakat. Terutama pemisah antara ruang bagi mereka yang mempunyai kemampuan ekonomi dan tidak.

Proses relasional atributif ditandai kata 'mempunyai'. AB berupaya untuk menegaskan harapan untuk mewujudkan persatuan antar-komponen masyarakat melalui kata 'mempunyai', yaitu hubungan yang sama (kesetaraan) antara kalangan masyarakat dengan ekonomi menengah ke atas dan masyarakat dengan menengah ke bawah.

Proses relasional identifikatif. Proses ini bertujuan untuk menguhubungkan suatu peristiwa dengan peristiwa lainnya. Karakteristik yang 
menandai proses ini adalah penutur melakukan identifikasi. Halliday dan Metthieseen (2004:210) memaknai proses relasional identifikatif sebagai the proses of being atau proses untuk mengenali dan menandakan suatu peristiwa tertentu dengan peristiwa lainnya. Partisipan dalam proses ini bertindak sebagai penunjuk (yang dijelaskan) dan tertunjuk (penjelasan). Proses ini digunakan untuk mengidentifikasi dan mengenali peristiwa tertentu berdasarkan persepsi penutur.

(13) Jakarta adalah tempat yang dipenuhi oleh sejarah.

Berdasarkan data (13), partisipan bertindak sebagai tertunjuk (penjelasan) adalah Jakarta, partisipan yang bertindak sebagi penunjuk (yang dijelaskan) adalah tempat yang dipenuhi oleh sejarah dan adalah bertindak sebagai penanda proses identifikasi. Identifikasi tersebut dapat diparafrasekan menjadi tempat yang dipenuhi oleh sejarah berada di Jakarta atau Jakarta menunjukkan tempat yang dipenuhi oleh sejarah. Dengan demikian, proses relasional ini menunjukkan adanya representasi situasi sosial di DKI Jakarta yang dulu pernah menjadi bukti sejarah bagi Indonesia.

\section{Proses Verbal}

Proses ini digunukan untuk menarik perhatian khalayak dengan menggunakan kutipan dari pihak tertentu yang memiliki hubungan dengan wacana sekaligus dikenal masyarakat. Partisipan dalam proses verbal memiliki hubungan dalam wacana, yaitu penutur (sayer) dengan penerima (recipient).

(14) Bang Sandi sudah jabarkan bagaimana kita bersama-sama membangun dan mengelola kampung, mengelola jalan, sekolah, puskesmas, pasar, angkot, dan berbagai aspek kehidupan lainnya. Seperti kata Bang Sandi, ini adalah satu langkah bersama ke depan memastikan Jakarta yang lebih ramah rimpi untuk semua",

Proses verbal dalam data (14) mengutip ungkapan pihak yang berhubungan dengan maksud AB, yaitu Sandiaga Uno untuk menarik perhatian masyarakat. Kutipan tersebut ditandai dengan kata 'sudah dijabarkan' dan 'seperti' sebagai tindakan verbal yang dilakukan sayer, sedangkan pembicaraannya adalah bahwa semua elemen masyarakat dengan status ekonomi yang berbeda-beda berhak mendapatkan keadilan.

\section{Appraisal dalam Fungsi Inte rpersonal}

Suatu wacana atau teks juga memiliki kekuatan emosional yang dapat membuat suatu teks bermakna bagi pembaca atau pendengar melalui sistem evaluasi. Sistem appraisal menyediakan beberapa fitur yang dapat digunakan untuk mengidentifikasi makna dalam sistem tersebut. Ada tiga jenis aspek sistem appraisal yang digunakan dalam penelitian ini, yaitu sikap (attitudes), tingkatan pernyataan (amplified), dan sumber evaluasi (source) (Martin dan Rose, 2003).

\section{Sikap (Attitude)}

Sikap yang ditunjukkan pembuat wacana menentukan hadirnya makna yang diterima pembaca atau pendengar. Dalam pidatonya, AB makna interpersonal yang dapat diidentifikasi melalui tiga aspek, yaitu pengaruh (affection), penilain (judgement), dan penghargaan (appreciation).

Pengaruh(affection). Aspek affection digunakan untuk mengekpresikan perasaan, baik yang positif maupun negatif secara langsung maupun tidak langsung.

(15) Dulu kita semua pribumi ditindas dan $\underline{\text { di- }}$ kalahkan.

Data (15) menunjukkan adanya ungkapan yang melibatkan perasaan (emosional) dari kata 'ditindas' dan 'dikalahkan' secara langsung dan lugas. Secara tidak langsung kedua kata ini akan mempengaruhi emosional masyarakat yang juga ikut merasakan ketidakadilaan saat itu saat mendengar ungkapan $A B$. Pengaruh ini juga diperkuat dengan data (16) berikut ini.

(16) Kita semua harus merasakan manfaat kemerdekaan di ibu kota ini.

AB mengungkapkan ekspresi yang melibatkan emosional secara tidak langsung melalui penggunaan kata 'merasakan'. Kata ini memiliki kekuatan emosional tersendiri karena berkaitan dengan perasaan seseorang. Upaya AB untuk menarik perhatian masyarakat agar berada dalam satu asumsi yang sama dengannya dapat dilihat dari aspek attitude ini.

Penilain (judgement). Penilaian yang dimaksud dalam suatu wacana adalah bagaimana 
pembuat wacana menyampaikan penilainnya terhadap karakter seseorang atau kelompok tertentu. Ada dua penilain, yaitu penilaian pribadi dan penilaian moral. Penilaian pribadi ditujukan pada karakter seseorang atau kelompok tertentu, sedangkan penilaian moral ditujukan pada kebijakan yang dibuat seseorang atau kelompok tertentu menyangkut kepentingan publik.

(17) Ikatan yang kemarin sempat tercerai, mari ikat kembali, mari kita rajut kembali, mari kita kumpulkan energi yang terserak menjadi energi untuk membangun kota ini bersama-sama.

Data (17) menunjukkan adanya sikap (attitude) yang dilakukan melalui penilaian (judgement) $\mathrm{AB}$ terhadap pihak lain yang dianggap memiliki pengaruh terhadap perhatian masyarakat dengan memasukkan peristiwa yang berkaitan dengan fokus pembicaraan tersebut. Penilaian yang diberikan melalui frase 'ikatan yang kemarin sempat terceria' merupakan penilaian moral untuk mengkritik pihak lain secara tidak langsung dalam peristiwa yang sebelumnya dianggap dapat menimpulkan perpecahan.

\section{Penghargaan (Appreciation)}

Penghargaan dalam suatu wacana terjadi karena tindakan/perilaku seseorang terhadap suatu peristiwa, biasanya berupa hal yang bersifat abstrak. Ada dua jenis penghargaan, yaitu penghargaan positif dan penghargaan negatif.

(18) Inilah semangat pembangunan yang kita letakkan sama-sama untuk Jakarta

Data tersebut menunjukkan bahwa $\mathrm{AB}$ berupaya menyampaikan penghargaan untuk menarik semangat masyarakat melalui 'inilah semangat pembangunan'. Penggunaan frase tersebut menggambarkan penghargaan yang tinggi untuk kemajuan pembangunan di DKI Jakarta yang $\mathrm{AB}$ harapkan sebagai gubernur baru.

\section{Tingkat Pernyataan (Amplified)}

Tingkatan pernyataan berkaitan dengan perasaan penulis terhadap apa yang sedang dirasakan. Tingkatan perasaan tersebut dapat berupa pujian, kiasan, sanjungan atau sindiran yang bersifat diperkuat atau diperhalus. Berikut salah satu data yang menunjukkan tingkat pernyataan $\mathrm{AB}$ dalam pidatonya.

(19) Pengelolaan tanah, pengelolaan air, pengelolaan teluk, dan pengelolaan pulau tidak boleh diletakkan atas dasar kepentingan individu. Pengelolaan itu semua tidak boleh untuk kepentingan satu golongan, tidak boleh untuk kepentingan satu perhimpunan, tidak boleh untuk kepentingan korporasi, tetapi itu untuk kepentingan warga Jakarta semua"

Klausa yang digarisbawahi pada data (19) secara tersirat mengindikasikan adanya pernyataan dari penegasan pada tingkat terkecil hingga terbesar 'kepentingan individu', 'kepentingan satu golongan', 'kepentingan satu himpunan', 'kepentingan korporasi' hingga 'kepen-tingan semua warga Jakarta'. Dalam menyampaikan penegasan tersebut, $\mathrm{AB}$ berupaya mengekspresikan sindiran yang diperhalus melalui kalimat larangan atau imperatif 'tidak boleh'. Pernyataan ini seakan merepresentasikan situasi antara masyarakat dan pemerintah yang dianggap kurang sinergi dan tidak atas kepentingan rakyat.

\section{Sumber Pernyataan (source)}

Salah satu aspek appraisal untuk mengidentifikasi adanya sumber pernyataan adalah modalitas atau 'keharusan'. Modalitas menjadi bagian untuk mengidentifikasi adanya peningkatan dalam menggali makna interpersonal melalui sistem appraisal. Modalitas membahas tentang keharusan yang ditegaskan oleh pembuat wacana kepada pendengar atau pembaca. Berikut beberapa data yang menunjukkan adanya tingkatan 'keharusan' yang semakin tinggi dalam pidato $\mathrm{AB}$

(20) Gubernur dan wakil gubernur tentu menjadi pemimpin bagi semua dan harus menghadirkan keadilan bagi semua. Namun, jelas kami tegaskan bahwa tekad kita adalah mengutamakan pembelaan yang nyata kepada mereka yang selama ini tak mampu membela dirinya sendiri”

Kata 'harus' pada data (20) menunjukkan modalitas yang kuat karena $\mathrm{AB}$ menggunakan kata tersebut secara langsung. Selain itu, pernyataan tersebut dipertegas lagi dengan klausa jelas kami tegaskan yang dapat menjadi fokus perhatian bagi khalayak. Keharusan tersebut 
menggarisbawahi 'keadilan' yang diharapkan bisa didapatkan kepada warga yang selama ini dianggap tidak mempu membela dirinya sendiri dari ketidakadilan. Berdasarkan penjelasan ini, sumber pernyataan yang menjadi tonggak penekanan $\mathrm{AB}$ dalam mengutarakan gagasannya adalah kata harus.

Berdasarkan uraian analisis pilihan kata, transitivitas, dan sistem appraisal yang ditemukan dalam pidato $\mathrm{AB}$ tersebut, representasi yang menggambarkan situasi DKI Jakarta dapat diidentifikasi. Hal ini membukutikan bahwa transitivitas sebagai salah satu aspek metafungsi bahasa dalam tataran analisis tekstual wacana kritis dapat menjembatani penggalian ideologi melalui representasi yang dimunculkan oleh pembuat wacana, dalam hal ini adalah $\mathrm{AB}$.

\section{Analisis Praktik Wacana Representasi Situasi Sosial DKI Jakarta}

Praktik wacana sebagai tahap kedua dalam kerangka analisis wacana kritis Fairclough, memanfaatkan proses produksi dan interpretasi teks. Penelitian ini berfokus pada interpretasi karena data yang digunakan tidak melihat proses produksi dari pembuat wacana, tetapi cara wacana tersebut dimaknai oleh pembaca atau pendengar. Tahap interpretasi berkaitan dengan hubungan antara teks dan interaksi dalam teks dengan melihat teks sebagai hasil produksi sekaligus sumber interpretasi. Interpretasi merupakan penggeneralisasian melalui apa yang ada dalam teks dan apa yang ada dalam benak interpreter. Selain itu, sebagai bagian dari praktik wacana, interpretasi juga melibatkan konteks suatu wacana, yaitu apa yang terjadi, siapa yang terlibat, bagaimana hubungan yang terjadi serta bagaimana peran bahasa pada teks tersebut (Fairclough, 2001).

Konteks yang menjadi fokus dalam penelitian ini adalah konteks situasional, yaitu praktik sosial dalam wacana tidak hanya sekadar rangkaian kalimat yang terdiri atas subjek, predikat, objek, dan fungsi bahasa lainnya (termasuk metafungsi bahasa), tetapi aspek lain di balik wacana tersebut 'tersembunyi' ideologi tertentu. Dengan demikian, interpretasi wacana dalam pidato $\mathrm{AB}$ tidak dapat dipisahkan dari analisis konteks yang meliputi teks karena wacana berhubungan dengan kepentingan tertentu yang dilatorbelakangi oleh ideologi tertentu.

Pertama, interpretasi dapat dilakukan berdasarkan pilihan kata dalam metafungsi teks- tual, salah satunya bertujuan untuk menunjukkan marginalisasi seperti terdapat pada data berikut ini.

(21) Dulu kita semua pribumi ditindas dan dikalahkan.

(22) Kita yang bekerja keras untuk merebut kemerdekaan. Kita yang bekerja keras untuk mengusir kolonialisme. Kita semua harus merasakan manfaat kemerdekaan di ibukota ini"

Berdasarkan data (21) dan (22), AB secara tersirat menunjukkan adanya marginalisasi terhadap pihak kolonial dengan menggunakan kosakata kolonialisme. Dalam konteks situasi masyarakat, terutama masyarakat Indonesia, kolonialisme sudah tidak disinggung setelah era berakhir pada tahun 1968. Selain itu, kata pribumi juga menunjukkan adanya marginalisasi yang dianggap sebagai pihak yang paling merasakan penjajahan dan penindasan pada era kolonialisme. Secara tidak langsung, kata kolonialisme memarjinalkan pihak kolonial sebagai pihak oposisi bagi pihak yang lebih inferior. Berdasarkan interpretasi tersebut, $\mathrm{AB}$ berupaya untuk membangun pemahaman masyarakat bahwa kolonialisme sudah semestinya berakhir dan benar-benar berganti menjadi kemerdekaan yang sesungguhnya.

Kedua, interpretasi yang dapat dilakukan berdasarkan transitivitas dalam metafungsi ideasional, salah satunya adalah melalui proses mental tipe perseptif. Transitivitas tersebut dapat dilihat kembali melalui data (23) berikut ini.

(23) Dan Jakarta ini satu dari sedikit, satu dari sedikit kota di Indonesia yang merasakan kolonialisme dari dekat. Penjajahan di depan mata itu di Jakarta, selama ratusan tahun. Di tempat lain mungkin penjajahan terasa jauh, tapi di Jakarta bagi orang Jakarta yang namanya kolonialisme itu di depan mata. Dirasakan sehari-hari

AB menegaskan secara eksplisit bahwa rakyat Jakarta adalah pihak yang paling sering melihat kolonialisme secara langsung dan dekat. $\mathrm{Hal}$ ini terlihat dari penggunaan verba merasakan yang dapat diinterpretasikan sebagai kegiatan yang melibatkan indera karena dihubungkan dengan konteks peristiwa yang dapat disaksikan langsung oleh mata. Hal ini menunjukkan bahwa kondisi Jakarta pada saat itu masih penuh dengan 
ketidakadilan yang dirasakan dan dilihat secara langsung oleh warga Jakarta. AB ingin menunjukkan kepada warga Jakarta tentang kepeduliannya terhadap keadilan, kesejahteraan, dan keamanan bagi seluruh rakyat Jakarta.

Ketiga, interpretasi berdasarkan metafungsi yang terakhir diidentifikasi melalui sistem appraisal, salah satunya adalah proses penilaian (judgement). Data berikut (24) menunjukkan proses tersebut untuk membentuk interpretasi yang merepresentasikan situasi sosial di DKI Jakarta dalam pidato pelantikan $\mathrm{AB}$.

(24) Ikatan yang kemarin sempat tercerai, mari ikat kembali, mari kita rajut kembali, mari kita kumpulkan energi yang terserak menjadi energi untuk membangun kota ini bersama-sama"

Penilaian (judgement) AB terhadap pihak lain yang berkaitan dengan peristiwa tercerainya elemen masyarakat adalah penilaian moral untuk mengkritik pihak lain secara tidak langsung dalam peristiwa yang sebelumnya dianggap dapat menimbulkan perpecahan. Hal ini dapat dikaitkan dengan konteks peristiwa yang sebelumnya terjadi di DKI Jakarta, yaitu adanya konflik antarumat beragama. Penilain tersebut menjadi representasi situasi DKI Jakarta melalui ungkapan AB dengan menonjolkan pencantuman peristiwa 'perceraian' dengan pihak lain yang jika diamati berkaitan dengan pemerintah DKI Jakarta sebelumnya.

Berdasarkan uraian interpretasi tersebut, proses interpretasi tidak dapat dipisahkan dari analisis ketiga metafungsi bahasa yang berfokus pada pilihan kata, transitivitas, dan sistem appraisal. Interpretasi tersebut tentu saja mengacu pada analisis mendalam dari peneliti yang sekaligus bertindak sebagai pembaca atau pendengar serta menjadi bagian dari khalayak atas wacana tersebut. Dengan demikian pengunaan bahasa $\mathrm{AB}$ dalam pidatonya melalui ketiga metafungsi bahasa dapat merepresentasikan situasi sosial di DKI Jakarta dalam tataran praktik penggunaan wacana.

\section{Konstruksi Ideologi}

Ideologi yang tercermin dalam pidato $\mathrm{AB}$ berdasarkan representasi melalui pilihan kata adalah Jakarta menjadi saksi terjadinya kolonialisme yang dianggap merugikan penduduk asli Jakarta atau yang disebut $\mathrm{AB}$ sebagai 'pribumi'. Hal inilah yang melatarbelakangi banyaknya penggunaan kata tersebut dalam pidatonya sebagai penekanannya terhadap ideologi yang mencerminkan keadilan, kesejahteraan, penjajahan, pribumi dan kemerdekaan. Selain itu, ideologi yang dapat diungkap berdasarkan representasi melalui transitivitas adalah keunggulan Jakarta tidak hanya sebagai ibukota, tetapi sekaligus menjadi tuan rumah bagi orang-orang dari seluruh bagian Indonesia maupun luar Indonesia. Hal ini didasarkan pada upaya $\mathrm{AB}$ untuk membuat citra dan kesan yang baik terhadap Jakarta beserta warganya dalam memulai pemerintahan.

Ideologi lainnya yang dapat diungkap berdasarkan representasi melalui sistem appraisal, yaitu citra tegas $\mathrm{AB}$ sebagai pemimpin baru melalui penggunaan modalitas 'harus' dan imperatif 'tidak boleh' yang melekat pada masalah keadilan. Hal ini menunjukkan bahwa ideologi yang melatarbelakangi pidato tersebut berkaitan dengan klaim yang dianggap penting dan benar untuk diperhatikan, yaitu keadilan bagi seluruh warga Jakarta. AB berupaya untuk mendeskripsikannya secara tersirat dengan menunjukkan tendensi kepada pihak tertentu, yaitu penegasan pada kata 'pribumi' yang dianggap sebagai tuan rumah Indonesia dan 'ikatan yang sempat tercerai' antargolongan yang berada di DKI Jakarta. Dengan demikian, ideologi yang nampak adalah AB sebagai pemimpin DKI Jakarta yang baru bersikap kritis terhadap isu ketidakadilan serta anti perpecahan antarkomponen masyarakat sebagai refleksi atas konflik yang terjadi antarumat beragama beberapa waktu lalu. Hal ini memperkuat klaim bahwa sebagai pemimpin baru ia ingin menciptakan citra 'gubernur yang prorakyat dan lebih baik', terutama dalam hal keadilan, kesejahteraan, dan persatuan.

\section{SIMPULAN}

Aspek analisis tekstual melalui pilihan kata, transitivitas, dan sistem appraisal serta praktik wacana melalui interpretasi teks dapat membentuk representasi situasi sosial di DKI Jakarta. Fitur-fitur ini menjadi piranti kebahasaan yang akhirnya dapat digunakan untuk mengungkap ideologi yang tercermin dalam pidato $\mathrm{AB}$ pada pelantikan Gubernur dan Wakil Gubernur DKI Jakarta periode 2017-2022.

Hasil dari penelitian ini menunjukkan bahwa situasi sosial DKI Jakarta yang meliputi identitas DKI Jakarta di masa lalu, situasi beberapa 
waktu terakhir, serta harapan yang akan dicapai di masa yang akan datang terepresentasi dalam pidato $\mathrm{AB}$ melalui ketiga fungsi bahasa dalam level analisis tekstual dan praktik wacana. Ideologi tertentu, yaitu kritik dan sorotannya terhadap masalah keadilan, kesejahteraan, penjajahan, pribumi dan kemerdekaan juga tercermin dalam pidato $\mathrm{AB}$ melalui level praktik sosiokultural. Ideologi ini sekaligus melatarbelakangi penggunaan bahasa dalam pidatonya sebagai upaya untuk membentuk citra 'gubernur yang akan bertindak prorakyat dan lebih baik' dari pemerintah sebelumnya. Berdasarkan analisis tersebut, istilah 'pribumi' dalam pidato $\mathrm{AB}$ yang sudah menjadi sorotan publik dapat dilihat sebagai ungkapan yang berkaitan dengan sikap kritisnya terhadap masalah kesetaraan dan keadilan bagi masya-

\section{DAFTAR PUSTAKA}

Basrowi. 2008. Memahami Penelitian Kualitatif. Jakarta: Rineka Cipta.

Eriyanto. 2009. Analisis Wacana: Pengantar Analisis Teks Media. Yogyakarta: LKiS.

Fairclough, N. 1995. Critical Discourse Analysis: the critical study of language. London: Longman.

Fairclough, N. 2001. Language and Power. London: Longman.

Fowler, R \& G. Kress. 1996. Language and Control. London: Routledge and Kegan Paul.

Fowler, R. 1991. Language in the News: Discourse and Ideology in the Press. London: Routledge

Faridi, M. 2014. Analisis Wacana Kritis Teks Berita Politik dalam Koran Radar Madura Menjelang Pemilu Legislatif 2014. Jurnal NOSI, 2(7): 710-715.

Hernandez, A. A. 2008. SFL and CDA: Contributions of the Analysis of the Transitivity System in the Study of the Discursive Construction of National Identity (Case Study: Gibraltar). The Linguistics Journal, 3(3): 160-175.

Intruksi Presiden Nomor 26 tahun 1998 tentang Menghentikan Penggunaan Istilah Pribumi dan rakat, khususnya warga DKI Jakarta dengan berefleksi terhadap peristiwa yang terjadi di masa lalu dan pemerintahan sebelumnya.

\section{UCAPAN TERIMA KASIH}

Artikel ini merupakan bagian dari penelitian tesis penulis di Program Studi Ilmu Linguistik, Universitas Gadjah Mada. Penulis menyampaikan terima kasih kepada Bapak B. R. Suryo Baskoro yang telah memberikan bimbingan dan arahan selama proses penelitian. Ucapan terima kasih diberikan pula kepada mitra bestari (reviewers) yang telah memberikan saran, kritik, dan rekomendasi perbaikan artikel ini

Non Pribumi dalam Semua Perumusan dan Penyelenggaraan Kebijkan, Perencanaan Program, ataupun Pelaksanaan Kegiatan Penyelenggaraan Pemerintahan.

Halliday, M. A. K. 1994. An Introduction to Functional Grammar. Edisi Kedua. London: Edward Anrnold.

Halliday, M. A. K. \& M. I. M. Matthiessen. 2004. An Introduction to Functional Grammar (Third Edition). London: Horder Arnold.

Martin, J. R. dan David Rose. 2003. Working with Discourse. London: Continuum.

Pemerintah Provinsi DKI Jakarta. 2017. Pidato Sambutan pelantikan Gubernur dan Wakil Gubernur DKI Jakarta 2017-2002. Online. http://www.jakarta.go.id/v2/news/category/sam butan, diakses: 11 November 2017.

Sudaryanto. 1993. Metode dan Aneka Teknik Analisis Bahasa. Yogyakarta: Duta University Press.

Undang-Undang Republik Indonesia Nomor 40 Tahun 2008 tentang Penghapusan Diskriminasi Ras dan Etnis. 